\section{$1 \mathrm{I1600}$}

\section{F1-ATPaseによるATP 合成の試み}

○伊藤博康 ${ }^{1.2}$ 、野地博行 2 、吉田賢右 ${ }^{2.3}$ 、木下一彦 ${ }^{2,4}$ (1 浜松ホトニクス (株) 筑波研究所、 ${ }^{2} \mathrm{CRESTチーム} 13$ 、 3 東I.大・資源研、 ${ }^{4}$ 慶大・理工・物理)

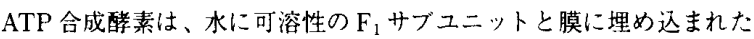
$\mathrm{F}_{0}$ サブエニットからなり、膜内外のプロトンの濃度勾配を利用して、 可逆的にATPの分解／合成を行う。 $F_{1}$ サブユニット部分は簡単に膜 から取り外すことができて、単体では、ATP 分解酵素として㗢く。 ATP分解の際に、 $F_{1}$ の $\gamma$ サブユニットが周冊の $\alpha_{3} \beta_{3}$ 艺ステーター として回転する回転モーターのローターであったことの確証は、この 䣼素をガラス基盤上に固定し、 $\gamma$ サブユニットに大きな目印（蛍光標 識したアクチンフィラメント)をとりつけるという回転アッセイ法の 確立が鍵であったと言えるだろう。我々は、この分子機械がどのよう な代掛けで働くのか、分子内で何が起きているのかを、光学顥微镜の 下で、1 分子が働いている現場を直接「見て操作する」ことにより解 明したいと考えている。大きな目印は、 $\gamma$ サブユニットを操作するた めのハンドルとしても用いることができる。目卵を直径 $1 \mu$ mの磁 気ビーズに変えて、外部から回転磁場を印加すると、ATP 存在下で、 $\gamma$ サブユニットとともに回転している磁気ビーズの回転を止めたり、 強制的に逆回転させることができた。磁場を取り除けば、磁気ビーズ は再びATPによる反時計回りの回転を開始する。さて、ADPと Pi の存在下で、逆回転（時計方向）を続ければ、 $F_{1}$ ATPascは、ATPを 合成することができるのだろうか？この問いに関しては、一昨年の年 回で、ATPの検出の効率の問題があることを議論した。ATPの検出 の効率の向上を目指した操作・計測システムを改良を行い、徐々に問 題を解決しつつある。まだ、試行数も少なく、ATPは、できるともで きないともいえない状態であるが、研究の進展について報告したい。

H. Itoh. H. Noji, M. Yoshida. and K. Kinosita, Jr. : Try to detect the mechanically synthesized ATP of $F_{1}$-ATPase

\section{$1 \mathrm{I} 1615$}

F1モーターの回転トルクを直接測定する

○野地博行 ${ }^{1}$ 、伊藤 博康 ${ }^{1}$ 、足立 健吾 ${ }^{1}$ 、吉田賢右 ${ }^{1,2}$ 、末下 一彦 ${ }^{1.3}$ ( ${ }^{1}$ CREST、 ${ }^{2}$ 東工大資源研、 ${ }^{3}$ 慶忍大物理)

F1 モーターはATP 合成醉素の膜表在性部分であり、ATP を加水分 解して分子中央の $\gamma$ サブユニットを问転させる回転分子モーターであ る。モーターの機能に必要最低限のサブユニット組成は $\alpha_{3} \beta_{3} \gamma \gamma て ゙$

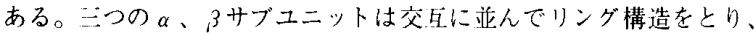
$\gamma$ サブニニットを取り曲んでいる。そして、三つのßが順番にATP を加水分解寸ることで、 $\gamma$ が一方向に间転する。この回転の様子は、 $\gamma$ に蛍光標識したアクチン線維を結合させ $\alpha_{3} \beta$ アリングをガラスに 固定することで、蛍光影微鏡を用いて観察することができる。F1モ一 夕一が出寸回転トルクは、 $\alpha_{3} 33$ リングと $\gamma$ の闑に生に゙る回転方向 のポテンシャルの傾きである。すなわち、各角度での回転卜ルクがわ かれば、このポテンシャルの形状をもとめることができる。これまて の奏験では、回転しているアクチン線維の長さと回転速度で決まる粘 性抵抗から回転卜ルクの值をもとめ、その値が角度に上らず抄拉よ そ40pNnmで一定であるとしている。しかし、この場合の问転トル クの值は、各角度での瞬間の回転速度で決まるために、正確に求めら れているとは言い難い。そこで今回は、アクチン線維の代わりに磁気 ビーズを $\gamma$ サブユニットに結合させ、外部から磁場を与えて回転を各 角度に推いて静止させた。この時に 見皘もることで、F1モータ一の回転卜ルクを測定することを陚みて いる。こ机によって、 $\alpha_{3} \beta$ アリングと $\gamma$ の間のポテンシャルの形を もとめることができるであろう。またさらに、この測定を ATPのア ナログである AMP-PNPや生成物であるADPもしくはPi 存在下で 行なうことで、ATP 加水分解に伴うポテンシャルの変化の解明が期 待できる。

H.Noji. H.Itoh, K.Adachi,M.Yoshida and K.Kinosita : Direct measurement of torque value of $F 1$ motor

\title{
$1 \mathrm{I} 1630$
}

\section{結合ヌクレオチド，構成サブュニット，温度が与える F $_{1}$-ATPaseの活性への影解}

○定立 健吾 ${ }^{1}$ 、安田 潦平 ${ }^{1}$ 、野地博行 ${ }^{1}$ 、吉田 賢存 ${ }^{2.3}$ 、木下 一彦2.3 ( ${ }^{2}$ CREST チーム $13 、 2$ 東工大・資源研、 ${ }^{3}$ 慶大・理 工. 物理)

ATP 合成醭素の一部分である $\mathrm{F}_{1}$-ATPase $\left(\mathrm{F}_{1}\right)$ はそれ自身が回転す る分子モーターである。回転子 $\gamma$ サブユニットは3つのßサブユニッ トと $3 つ の \alpha$ サブユニットに取り用まれており，及サブエニットでの ATP加水分解にともなって回転が扰こっている。

ATP 再生系を用いた $F_{1}$ の溶液中での ATP 加水分解測定に扔いて，活 性は測定開始直後最も高く，しだいに減少し，最終的に一定になる。 この現象は MgADP 阻害と呼ばれる $F_{1}$ の性質で, ATP 加水分解に よって生じるADPがある確率で $F_{1}$ を不活性な状態にするためであ る。我々は開始直後の最も高い活性を MgADP 阻害の無い状態での $\mathrm{F}_{1}$ の活性と考え，顕微鏡下で観察した 1 分子の回転速度と比較した。無 負荷に近い条件で測定された 1 分子の回転速度（昨年報告された安田 らのデータ)は，加水分解活性から期待される值より高加た。ADP 阻害以外の原因があるのだろうか。

我々は温度の活性に対する影響を検討した。我々の使う高熱菌丮来の $\mathrm{F}_{1}\left(\alpha_{3} \beta_{3} \gamma\right.$ サブコンプレックス)を水温で 24 時間放置したときは, $23^{\circ} \mathrm{C}$ で放置したものよりも約 $60 \%$ まで活性が隇少した。ゲル滤過 HPLC で調べたところ，低温ではサブコンプレックスの解離が進んでいた。 温度はコンプレックスの安定性に重要で，へテロな分子が活性に影笪 を与えることが見かけの低い活性の原因であろうと考えられる。さら に, 活性測定開始以前加結合しているヌクレオチドの数， $\alpha \beta \gamma$ 以 外のサブユニットの影柿などを検討している。

K. Adachi. R. Yasuda. H. Noji, M. Yoshida and K. Kinosita. Jr. The effect of bound nucleotide, subunit composition and temperature on the ATPase activity of $F_{1}$-ATPase

\section{$1 \mathrm{I1645}$}

\section{F $_{1}$-ATPase による ATP の加水分解と回転の同時 観察}

○西坂崇之 1 、足立健吾 ${ }^{1}$ 、野地博䘕 ${ }^{1}$ 、大岩和弘 ${ }^{2}$ 、安田 涼 平 1 、枺 楌1.3 ( ${ }^{1}$ CREST「生命活動のプログラム」チー 厶 $13 、{ }^{2}$ 通信稳合研究所・関西支所、 3 慶大・理・物理)

回転分子モーターである $F_{1}$-ATPase 1 分子に対するATP の結合。 解離と、その回転の同時観察を行った。 $\mathrm{F}_{1}$ をガラス面に固定し、回 転軸である $\gamma$-shaft に微小ビーズ（直径 $0.2 / \mathrm{m}$ ) 数個の集合体を結 合させて、波長 $\geqq 660 \mathrm{~nm}$ の明視野像としてビーズをとらえる。ATP の結合・解離は、蛍光性の ATP 1 分子をレーザー(波長 $532 \mathrm{~nm}$ )

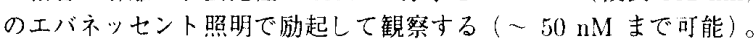
$\mathrm{F}_{1}$ には3つの ATP 加水分解年イトがあり、連続的な回転に扩いて は1個以上の ATPが絶えず結合していると考えられるので、通常の 無標識の ATP を過剩にし (100)-400 $\left.\mathrm{nM}, k_{i m}-10^{7} \mathrm{M}^{-1} \mathrm{~s}^{-1}\right)$ 、蛍光 性 ATPがー 1 分に 1 回結合するような条件 (50 nM. $k_{0 m} \sim 4 \times 10^{5}$ $\mathrm{N}^{-1} \mathrm{~s}^{-1}$ )で回転の観察を試みた。蛍光性 ATP が綃合すると、F、は $120 \mathrm{deg}$. のステップ状の回転を行った。蛍光強度と回転の解析にはそ れぞれビデオフレーム (33 ms) \pm 1 程度の誤差があると仮定し、フ レーム \pm 2 の範囲で調べところ、 $91 \%$ のンプル $(\mathrm{N}=68)$ において ATP の結合とステップのタイミングは同期していた。興味深いこと に、蛍光性 ATP が解離する前に 2 番目のステップが観察され( $83 \%$, $\mathrm{N}=47$ )、さらに蛍光性 ATP の解離と 3 番目のステップもやはり同 期した $(79 \% . \mathrm{N}=33) 。 2 、 3$ 番目のステップは無標識の ATP の結 合/加水分解によるものだと考えられる。今回の絬果は蛍光性 ATP を甹むものだが、これが通常のATP だけによる同転にも当てはまる とすると、ル M 以下の ATP 濃度に执いても、2 個以上のヌクレオ チドが问転運動の間に絶えず結命しているようなメカニズムを考える 必要があるかも知れない。

T. Nishizaka, K. Adachi, H. Noji. K. Oiwa, R. Yasuda and K. Kinosita Jr. : Simultaneous observation of stepwise rotation and single ATPase by $F_{1}$-ATPase 